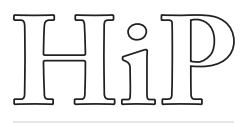

Historia i Polityka

Nr $13(20) / 2015$, ss. 97-106

ISSN 1899-5160

www.hip.umk.pl

DOI: http://dx.doi.org/10.12775/HiP.2015.006

Marcin KOŃCZAL

Uniwersytet im. Adama Mickiewicza w Poznaniu

\title{
Geneza konfrontasi: główne przyczyny indonezyjsko-malezyjskiego konfliktu zbrojnego o przyszłość wyspy Borneo w latach 1963-1966
}

\section{The Origins of konfrontasi: Main Reasons of Indonesian-Malaysian Armed Conflict over the Future of the Borneo Island between 1963 and 1966}

\begin{abstract}
The article discusses the main causes of the konfrontasi - armed conflict between Indonesia and Malaysia, supported by Great Britain, Australia and New Zealand, especially in the context of the future of Borneo Island. The article focuses its attention on the meaning and etymology of the term konfrontasi, describes the administrative division and demographic composition of Borneo Island in the beginning of the sixties, as well as presents the most important causes of the outbreak of war, with particular emphasis on the political situation in the former British colony of Sarawak and Brunei.
\end{abstract}

Keywords: Indonesia, Malaysia, konfrontasi, Borneo, Sukarno

Słowa kluczowe: Indonezja, Malezja, konfrontasi, Borneo, Sukarno

\section{Konfrontasi-znaczenie i pochodzenie terminu}

Konfrontasi - pochodzący z języka indonezyjskiego termin oznaczający „konfrontację"1. Pojawił się w kontekście stosunków międzynarodowych w czasie intensywnie rozwijającego się konfliktu zimnowojennego w pierwszej połowie lat sześćdziesiątych dwudziestego wieku. Odnosi się do wrogich relacji między Indonezją, a wspieraną przez Wielką Brytanię, Australię i Nową Zelandię Malezją, głównie w kontekście przyszłości północnej część wyspy Borneo².

${ }^{1}$ Konfrontasi w: Concise Indonesian Dictionary, red. A.L.N. Kramer Sr., W. Koen, K. Davidson, Rutland 2007.

${ }^{2}$ Zob. Zimna wojna (1946-1989) i jej konsekwencje dla tadu międzynarodowego, red. S. Wojciechowski, B. Koszel, Poznań 2007; Zimna wojna: sprzeczności, konflikty i punkty kulminacyjne w radziecko-amerykańskiej rywalizacji, red. W. Malendowski, Poznań 1994. 
W warunkach indonezyjskich, co zauważył Jamie Mackie „termin ten znajduje się w ogólnym obiegu już od wielu lat. Pierwotnie odnosił się bowiem do kontrastu pomiędzy tradycyjnym a nowoczesnym sposobem myślenia i kulturowej ekspresji. Odwieczny konflikt między dwoma grupami postaci z tradycyjnego teatru cieni zwanego wayang był dosłownie określany jako konfrontujący, gdzie postacie umieszczone po przeciwnych stronach niezwykle sformalizowanej tablicy [stanowiącej tło dla przedstawienia przypomina M.K.] angażowały się w debatę werbalną bądź w fizyczną bójkę, w czasie której najważniejszą rolę odgrywały ponadnaturalne zdolności poszczególnych bohaterów”’3.

Dobry przykład ilustrujący tezę J. Mackie stanowi wayang Diponegoro, zwany w nomenklaturze anglojęzycznej „operą Diponegoro” - rodzaj tradycyjnej indonezyjskiej sztuki teatralnej opisującej losy dziewiętnastowiecznego jawajskiego księcia Diponegoro, który przez pięć lat walczył przeciwko obecności holenderskiego kolonizatora na Jawie $e^{4}$.

Druga cześć niniejszej sztuki koncentruje się na wspomnianej konfrontacji pomiędzy rolnikami z Tagalreja, a Holendrami. W najnowszych wersjach spektaklu scena w humorystyczny sposób ukazuje rolników, którzy w języku indonezyjskim narzekają na rosnące podatki i budowę nowej drogi, która wielu z nich pozbawiła części własnej ziemi. Gdy jeden z rolników określa nową drogę mianem autostrady, niemal cała publiczność wybucha śmiechem. W ten sposób autor sztuki odnosił się do wszechobecnej korupcji i kumoterstwa na Jawie za czasów rządów generała Suharto.

Ten charakterystyczny efekt zestawienia dwóch pozornie nie korespondujących ze sobą wydarzeń historycznych jest bardzo powszechnym zabiegiem stosowanym w indonezyjskich teatrach cieni'.

${ }^{3}$ J.A.C. Mackie, Konfrontasi: The Indonesia-Malaysia Dispute, 1963-1966, Kuala Lumpur 1974, s. 11; na temat indonezyjskiego teatru cieni zob. szerzej: A.L. Becker, Text-Building, Epistemology, and Aesthetics in the Javanese Shadow Theatre, [w:] The Imagination of Reality: Essays in Southeast Asian Coherence Systems, red. A. Yengoyan, A.L. Becker, Norwood 1979; B. James, On Thrones of Gold - Three Javanese Shadow Plays, Cambridge 1970; K. Ward, Javanese Shadow Plays, Javanese Selves, Princeton 1987.

${ }^{4}$ B. Osnes, The Shadow Puppet Theater of Malaysia: A Study of Wayang Kulit with Performances Scripts and Puppet Designs, Jefferson 2010, s. 23.

5 Sumarsam, Javanese Gamelan and the West, Rochester 2013, s. 55-79. 


\section{Podział administracyjny i skład demograficzny wyspy Borneo}

Na początku lat sześćdziesiątych wyspa Borneo administrowana była przez dwa różne podmioty prawa międzynarodowego. Południowa cześć wyspy zwana Kalimantanem składała się z czterech prowincji podległych rządowi w Dżakarcie, zaś północna część wyspy obejmowała Sułtanat Brunei - ówczesny protektorat brytyjski, oraz dwie kolonie Wielkiej Brytanii - Brytyjskie Borneo Północne (przemianowane następnie na Sabah) oraz Sarawak ${ }^{6}$.

Obszar administrowany przez Wielką Brytanię zamieszkiwało około półtora miliona obywateli, z czego blisko połowę stanowili Dajakowie - grupa ponad dwustu niezorganizowanych politycznie tubylczych plemion posługujących się różnymi językami ojczystymi ${ }^{7}$.

Zgodnie z danymi zamieszczonymi w tabeli 1. większość obywateli niewielkiego, bo zaledwie osiemdziesięciotysięcznego Sułtanatu Brunei stanowili na początku lat sześćdziesiątych Malajowie, których liczba przekraczała czterdzieści tysięcy. Drugą grupą etniczną tego brytyjskiego protektoratu byli obywatele pochodzenia chińskiego, stanowiący 28\% jego wszystkich mieszkańców.

Większość mieszkańców brytyjskiej kolonii Sabah, bo aż $72 \%$, stanowiły ludy tubylcze, w tym Dajakowie. Drugą co do wielkości grupę etniczną reprezentowali Chińczycy (21\%), a trzecią Malajowie (7\%).

Kolonia Sarawak w 50\% zasiedlona była przez ludy tubylcze, podczas gdy Chińczycy stanowili tam około $31 \%$ ogólnej populacji. Trzecią co do wielkości grupą byli Malajowie, stanowiący $19 \%$ obywateli prowincji.

Tabela 1. Skład demograficzny północnej części wyspy Borneo administrowanej przez Wielką Brytanię w roku 1960

\begin{tabular}{|l|l|l|}
\hline Sułtanat Brunei & Sabah & Sarawak \\
\hline Malajowie $-54 \%$ & Malajowie $-7 \%$ & Malajowie $-19 \%$ \\
\hline Chińczycy $-28 \%$ & Chińczycy $-21 \%$ & Chińczycy $-31 \%$ \\
\hline pozostali $-18 \%$ & pozostali $-72 \%$ & pozostali $-50 \%$ \\
\hline
\end{tabular}

Źródło: http://www.esa.un.org/unpd/wpp/index.htm, odczyt z 18.08.2014.

${ }^{6}$ Ooi Keat Gin, Post-war Borneo, 1945-1950: Nationalism, Empire and State-Building, Abingdon 2013.

${ }^{7}$ Ibidem; V.T. King, Dayaks, [w:] Southeast Asia: A Historical Encyclopedia from Angkor Wat to East Timor, red. Ooi Keat Gin, Santa Barbara 2003, s. 403-404. 


\section{Kwestia Nowej Gwinei Holenderskiej}

Niebywale istotne dla genezy konfliktu indonezyjsko-malezyjskiego były dwie następujące bezpośrednio po sobie kampanie antykolonialne pod przywództwem ówczesnego prezydenta Indonezji Sukarno ${ }^{8}$, które na dobre ustaliły priorytety indonezyjskiej polityki zagranicznej po proklamowaniu przez to państwo niepodległości w dniu 17 sierpnia 1945 roku?

Pierwszym z nich była kwestia Nowej Gwinei Holenderskiej, drugim zaś sprzeciw Indonezji wobec powstałej w roku 1957 Federacji Malajskiej i jej planów połączenia byłych kolonii brytyjskich mieszczących się na Półwyspie Malajskim z tymi, które znajdowały się na wyspie Borneo. W obu przypadkach Sukarno widział przejawy neokolonializmu, któremu kategorycznie się sprzeciwiał, czemu dał wyraz w przemówieniu wygłoszonym podczas Konferencji w Bandungu w 1955 roku $^{10}$.

Jak mówił: „(...) nie myślcie o kolonializmie tylko w jego tradycyjnej formie, jaką my Indonezyjczycy, jak również nasi bracia w Azji i różnych częściach Afryki poznaliśmy. Kolonializm przybiera bowiem również nowoczesną formę, w postaci ekonomicznej, intelektualnej, jak również fizycznej kontroli niewielkich lecz obcych społeczności nad całymi narodami. (...) Gdziekolwiek, kiedykolwiek i w jakikolwiek sposób będzie się objawiał - kolonializm jest procesem złym, który należy natychmiast usunąc'"11.

W związku z powyższym wystąpieniem i poglądami prezydenta, Sukarno uważał pomysł aneksji kolonii Sabah i Sarawak oraz przyłączenie ich do Federacji Malezji za działanie wrogie wobec Indonezji i osobisty afront ze strony Malajów, a także chęć swoistego okrążenia Indonezji przez Wielką Brytanię ${ }^{12}$.

Bezpośrednio przed samą konfrontacją Sukarno koncentrował swoje działania na próbie przyłączenia terytorium Nowej Gwinei Holenderskiej, będącej ostatnim

${ }^{8}$ W niektórych, szczególnie wcześniejszych publikacjach nadal można spotkać się z pisownią nazwiska pierwszego prezydenta Republiki Indonezji za pomocą połączenia liter „o” i „„” (Soekarno) charakterystycznego dla języka niderlandzkiego, którym posługiwały się władze kolonialne. Połączenie to zostało zastąpione literą „u” wraz z wprowadzeniem reformy ortograficznej w roku 1947 , zob. C. Genetti, How Languages Work: An Introduction to Language and Linguistics, Cambridge 2014, s. $557-563$.

9 M.C. Ricklefs, Sejarah Indonesia Modern: 1200-2008, Dżakarta 2008, s. 489; K.S. Yudiono, Pengantar Sejarah: Sastra Indonesia, Dżakarta 2010, s. 51, 115; faktycznie Indonezja stała się niepodległym państwem 27 grudnia 1949 roku.

${ }^{10}$ V. Matheson Hooker, A Short History of Malaysia: Linking East and West, Crows Nest 2003, s. 9; A. Vickers, A History of Modern Indonesia, Cambridge 2005, s. 154.

${ }^{11}$ Pełny tekst przemówienia prezydenta Sukarno wygłoszonego na Konferencji w Bandungu: http://www.fordham.edu/halsall/mod/1955sukarno-bandong.html, odczyt z 19.09.2014.

12 D.F. Anwar, Indonesia in ASEAN: Foreign Policy and Regionalism, Singapur 1994, s. 25. 
symbolem holenderskiego kolonializmu na tych ziemiach, do niepodległej Indonezji. Prezydent pragnął tym samym udowodnić opinii międzynarodowej, iż kierowane przez niego państwo jest liczącą się siłą w regionie o mocarstwowych ambicjach, w czym wspierała go Moskwa i Pekin ${ }^{13}$.

Mimo nieustających działań dyplomatycznych w latach 1950-1952 mających na celu przejęcie Nowej Gwinei Holenderskiej, społeczność międzynarodowa reprezentowana przez Zgromadzenie Ogólne Organizacji Narodów Zjednoczonych nie wyrażała na to zgody, motywując swój sprzeciw aktywnym udziałem Indonezji w Ruchu Państw Niezaangażowanych i organizacją Konferencji w Bandungu ${ }^{14}$.

W kryzysowym roku 1958 administracja prezydenta Sukarno stłumiła dwie groźne cywilno-militarne antyrządowe rebelie: skoncentrowaną w miejscowości Manado na północnym Sulawesi ${ }^{15}$ Permestę oraz bunt zorganizowany na Sumatrze przez samozwańczy Rewolucyjny Rząd Republiki Indonezyjskiej. Fakt ten spowodował, iż Indonezja zyskała opinie znaczącej siły militarnej w regionie, a prezydent Sukarno podjął odważną decyzję o przeprowadzeniu ataku zbrojnego na Nową Gwineę Holenderską ${ }^{16}$.

W dniu 18 grudnia 1961 roku wojska indonezyjskie dokonały napaści zbrojnej na Nową Gwineę Holenderską. Po blisko roku walk i nieustających wysiłkach dyplomatycznych, głównie ze strony amerykańskiego mediatora Ellswortha Bunkera, 15 sierpnia 1962 roku strony konfliktu podpisały Porozumienie Nowojorskie nakazujące Holendrom wycofanie się z Nowej Gwinei, która od tego momentu przeszła tymczasowo pod auspicje ONZ. Zgodnie z postanowieniem traktatu pokojowego do roku 1969 Dżakarta zobowiązała się do przestrzegania przepisu o tzw. „wolnym wyborze”, zgodnie z którym to sami mieszkańcy byłego terytorium Nowej Gwinei Holenderskiej mieli zadecydować o swojej przynależności państwowej ${ }^{17}$.

Zgodnie z postanowieniem Porozumienia Nowojorskiego w lipcu roku 1969 doszło do plebiscytu z udziałem mieszkańców, którego wynik zadecydował o formalnej integracji dawnej Nowej Gwinei Holenderskiej (zwanej teraz Zachodnią Papuą) z Republiką Indonezji. Zdaniem obserwatorów, a także znacznej grupy Pa-

${ }_{13}$ The Non-Aligned Movement and the Cold War: Dehli-Bandung-Belgrade, red. N. Mišković, H. Fischer-Tiné, N. Boškovska, Abingdon 2014, s. 328.

${ }_{14}$ Bandung Revisited: The Legacy of the 1955 Asian-African Conference for International Order, red. See Seng Tan, A. Acharya, Singapur 2008, s. 1.

${ }_{15}$ Indonezyjska nazwa wyspy Celebes.

${ }_{16}$ M.C. Ricklefs, A History of Modern Indonesia since c.1200, Stanford 2001, s. 319; zob. także: B.S. Harvey, Permesta: Half a Rebellion, Londyn 2009; Syamandi, PRRI: Pemberontakan atau bukan?, Dżakarta 2009.

17 Ibidem, s. 328. 
puasów, organizacja plebiscytu była „daleka od uczciwej”. W referendum, zamiast przeszło ośmiu tysięcy uprawnionych, udział wzięła grupa 1022 przywódców papuaskich plemion pod ścisłym nadzorem wojsk indonezyjskich ${ }^{18}$.

Spora grupa przeciwników integracji z Indonezją, wspierana przez holenderską politykę popularyzacji papuaskiej tożsamości narodowej, skupiła się w separatystycznej Organizacji Wolności Papui, która do dnia dzisiejszego aktywnie działa na rzecz pełnej niezależności tego regionu ${ }^{19}$.

\section{Sytuacja polityczna w Sarawaku}

Zakończenie II wojny światowej przyniosło kres panującej w Sarawaku dynastii Brooków, zwanych „Białymi Radżami”. Charles Vyner ostatni z Brooków stojący na czele Sarawaku, przekonany o słuszności podejmowanej decyzji i korzyściach, które mogą z niej wyniknąć na rzecz swoich poddanych, przekazał panowanie nad rodzinnymi ziemiami Koronie Brytyjskiej, która administrowała nimi z londyńskiego Biura do spraw Kolonii przy pomocy specjalnie do tego wyznaczonego gubernatora ${ }^{20}$.

Decyzja Charlesa Brooka nie została jednak przyjęta pozytywnie przez większość mieszkańców Sarawaku, liczących na pełną niepodległość i jednocześnie podkreślających silną lojalność w stosunku do rodziny Brooków. Sprzeciw wyraził również „Młody Radża” Anthony Brook, formalny następca Charlesa, który stanął na czele ruchu sprzeciwiającego się dokonanej „pospiesznie i niezdarnie" cesji ${ }^{21}$.

3 grudnia 1949 roku Sir Duncan George Stewart drugi gubernator Sarawaku przebywający z wizytą w mieście Sibu został raniony przez czterech członków organizacji Rukun 13, zrzeszającej grupę mężczyzn przeciwnych przejęciu Sarawaku przez Wielką Brytanię. Po kilku dniach spędzonych w singapurskim szpitalu Stewart zmarł, a czterej członkowie Rukun 13: Rosli Dhoby, Awang Ramli Amit Mohd Deli, Morshidi Sidek i Bujang Suntong zostali uznani za winnych jego śmierci po czym osadzono ich w więzieniu w Kuchingu. Zdaniem wielu współ-

18 Raport organizacji Human Rights Watch, Protests and Punishment: Political Prisoners in Papua, 2007, s. 9; http://www.hrw.org/sites/default/files/reports/papua0207webwcover.pdf, odczyt z 19.09.2014.

19 R. Crocombe, Asia in the Pacific Islands, Suva 2007, s. 286-291.

${ }^{20}$ S. Runciman, The White Rajahs: A History of Sarawak from 1841 to 1946, Cambridge 1960, s. $243-264$.

${ }^{21}$ Ibidem. 
czesnych historyków wydarzenia tego okresu przyczyniły się do powstania późniejszego ruchu antymalezyjskiego kierowanego przez Ahmada Zaidi Adruce ${ }^{22}$.

W latach pięćdziesiątych Sheikh Azahari bin Sheikh Mahmud, lider Partii Ludowej Brunei blisko związany z prezydentem Indonezji Sukarno i popierany przez składającą się w większości z Chińczyków Komunistyczną Organizację Sarawaku, wysunął propozycję unifikacji całego Brytyjskiego Borneo i stworzenie niepodległego Kalimantanu Północnego. Jednak ku jego zaskoczeniu, partia polityczna, z której się wywodził nie stała w kompletnej opozycji do brytyjsko-malajskiej idei Federacji Malezji. Ludowa Partia Brunei rozważała bowiem zgodę na przyłączenie się do Federacji pod warunkiem połączenia terytorialnego dwóch dawnych brytyjskich kolonii i protektoratu Brunei z głową państwa w postaci wspólnego sułtana. W ten sposób Ludowa Partia Brunei chciała zabezpieczyć się na wypadek ewentualnej chęci dominacji ze strony Singapurczyków, administracji malajskiej z Kuala Lumpur lub chińskich kupców ${ }^{23}$.

Koncepcja stworzenia Kalimantanu Północnego bardzo często określana była mianem post-dekolonizacyjnej alternatywy dla planu brytyjsko-malajskiego. Lokalna opozycja z Borneo podkreślała ekonomiczną, polityczną, historyczną, jak również kulturową odrębność od mieszkańców Półwyspu Malajskiego.

Mimo opozycji Sarawaku w dniu 16 września 1963 roku Federacja Malajów, Singapur, jak również dwie byłe kolonie brytyjskie na północnym Borneo: Sarawak i Sabah połączyły się tworząc Federację Malezji, co dało pretekst indonezyjskiemu prezydentowi do rozpoczęcia akcji militarnej ${ }^{24}$.

\section{Pucz brunejski}

W styczniu 1968 roku, krótko po dewaluacji funta, brytyjski premier Harold Wilson wraz z ówczesnym ministrem obrony narodowej Denisem Healeyem ogłosił, iż wojska Wielkiej Brytanii do roku 1971 wycofają się ze swoich głównych baz w Azji Południowo-Wschodniej (głównie z Malezji i Singapuru), jak również z Zatoki Perskiej i Malediwów. Zanim to jednak nastąpiło, już w latach pięćdziesią-

${ }^{22}$ Ibidem; Cheah Boon Kheng, Malaysia: The Making of Nation, Singapur 2002, s. 60.

${ }^{23}$ Ooi Keat Gin, The Cold War and Its Impact on Indonesia: Domestic Politics and Foreign Policy, [w:] Southeast Asia and the Cold War, red. A. Lau, Abingdon 2012, s. 118.

24 Sułtanat Brunei pozostał poza nową Federacją i dopiero 1 stycznia 1984 roku uzyskał pełną niepodległość z rąk Brytyjczyków; J.W. Gould, The United States and Malaysia, Cambridge 1969, s. 89; The Cambridge History of Southeast Asia: From II World War to the present, red. N. Tarling, Cambridge 1999, s. 127. 
tych rząd Wielkiej Brytanii rozpoczął rewizję swojej obecności militarnej na Dalekim Wschodzie, a jako część procedury wycofywania swoich sił zbrojnych zaproponował nowopowstałej Federacji Malajskiej rozszerzenie swych granic o Singapur i brytyjskie kolonie na Północnym Borneo ${ }^{25}$.

W roku 1971 rządy Wielkiej Brytanii i Federacji Malajskiej oficjalnie zaproponowały uformowanie Federacji Malezji, w której skład wchodziłyby dotychczasowe stany Federacji Malajskiej, Północne Borneo, Sarawak, Singapur i Sułtanat Brunei. Co ciekawe, w początkowej fazie Indonezja wykazywała łagodne wsparcie dla nowego pomysłu, mimo silnego sprzeciwu Indonezyjskiej Partii Komunistycznej ${ }^{26}$.

Zagrożeniem dla pomysłu stworzenia Federacji Malezji w kształcie zaproponowanym przez Wielką Brytanię i Federację Malajską okazał się ówczesny Sułtan Brunei Omar Ali Saiffudien III, który z obawy przed utratą silnej politycznej pozycji opowiadał się za całkowitą niepodległością, motywując swoją decyzję finansową gotowością Brunei na niezależność, wynikającą w głównej mierze z posiadanych złóż ropy naftowej. Wtórował mu w tym pomyśle Azahari bin Sheikh Mahmud, prominentny brunejski polityk i weteran indonezyjskiej wojny o niepodległość, równocześnie opowiadający się za unifikacją całego terytorium północnego Borneo $^{27}$.

W 1961 roku Mahmud otwarcie zwrócił się o pomoc do rządu indonezyjskiego, który w odpowiedzi rozpoczął militarne szkolenia niewielkich grup ochotników nazwanych później Narodową Armią Północnego Kalimantanu (TNKU) ${ }^{28}$.

8 grudnia 1962 roku TNKU rozpoczęło pucz - zwany rewoltą w Brunei, przez wielu uważany za bezpośrednie preludium późniejszej wojny indonezyjsko-malezyjskiej. W ten sposób rozpoczęcie powstania wspomina George McTurnan Kahin: „(...) to właśnie rebelia, która wybuchła 8 grudnia 1962 roku na terytorium Sułtanatu Brunei - obszaru, który miał stać się częścią przyszłej Federacji Malezji, miała kluczową rolę w późniejszym sprzeciwie Indonezji i Filipin wobec pomysłu powołania do życia nowego państwa. Przed incydentem próżno było szukać wyraźnych znaków sprzeciwu tych państw wobec brytyjskiego pomysłu stworzenia Malezji, nawet jeśli w jej skład wejść miało terytorium północnego Borneo”29.

${ }^{25}$ K. Kyle, Suez: Britain's End of Empire In the Middle East, Londyn 2011, s. 119-123; East of Suez and the Commonwealth 1964-1971, red. S.R. Ashton, W.R. Louis, Norwich 2004, s. 289-395.

26 K. Conboy, Kompassus - Inside Indonesia's Special Forces, Dżakarta 2003, s. 93-95.

27 G. McTurnan Kahin, Southeast Asia: A Testament, Londyn 2003, s. 160.

28 H.A. Majid, Rebellion in Brunei: The 1962 Revolt, Imperialism, Confrontation and Oil, Londyn 2007, s. 76-79.

29 G. McTurnan Kahin, op. cit., s. 160. 
Wystąpienie słabo wytrenowanych i kompletnie niewyposażonych sił TNKU przeciwko władzy kierowanej przez Sułtana, wspieranego przez siły brytyjskie okazało się kompletnym nieporozumieniem. Powstańcy nie byli w stanie zagrozić personalnie monarsze, nie dysponowali również wystarczającymi siłami do zajęcia brunejskich pól naftowych. W przeciągu zaledwie trzydziestu godzin od rozpoczęcia buntu, wojska brytyjskie (w większości Brygady Gurkhów) stacjonujące na terytorium Singapuru, wkroczyły do Brunei aby zapewnić bezpieczeństwo jego mieszkańców oraz Sułtana ${ }^{30}$. Do pomocy w niedopuszczeniu do ucieczki ochotników z TNKU zaangażowano również około cztery tysiące członków „niezwykle bitnego"31 tubylczego plemienia Kelabit, którzy wspólnie z siłami brytyjskimi do 18 maja 1963 roku zatrzymali ostatnich aktywistów TNKU ${ }^{32}$.

Do dnia dzisiejszego przedmiotem debaty pozostaje faktyczny stopień wsparcia udzielony TNKU przez rząd indonezyjski. Mimo, iż strona indonezyjska zaprzecza jakoby udzieliła bezpośredniej pomocy rebeliantom, faktem jest, iż sympatyzowała z ich działaniami mającymi doprowadzić do ostatecznego upadku koncepcji Federacji Malezji.

Po porażce militarnej TNKU, 20 stycznia 1963 roku indonezyjski minister spraw zagranicznych Subandrio na znak wsparcia dla Brunei ogłosił oficjalnie, iż Indonezja wycofuje się z dotychczasowej linii politycznej i zamiast wspierać brytyjskie pomysły, od tego momentu będzie aktywnie prowadzić politykę konfrontacyjną wobec Federacji Malajskiej. Zgodnie z zapowiedzią, 12 kwietnia 1963 roku, indonezyjskie siły zaatakowały posterunek policji w mieście Tebedu w prowincji Sarawak ${ }^{33}$.

Zdaniem Guya J. Paukera poprzez konfrontasi Sukarno w bezdyskusyjny sposób zamanifestował priorytet $\mathrm{w}$ swojej polityce, jakim okazała się ekspansja zewnętrzna, podkreślająca niszczycielski potencjał Indonezji jako największego i najpotężniejszego militarnie państwa regionu ${ }^{34}$. Tym samym prezydent na dalszy plan odłożył palące kwestie rozwoju wewnętrznego państwa ${ }^{35}$.

${ }^{30}$ H.A. Majid, op. cit., s. 78, M. Chappell, The Gurkhas, Oksford 1994, s. 11, zob. także: C. Lord, Ch. Lord, G. Vatson, The Royal Corps of Signals: Unit Histories of the Corps (1920-2001) and Its Antecedents, Solihull 2004.

31 Zob. szerzej: W. Breuer, Nieznane wojny McArthura, Warszawa 2002.

32 T. Pocock, Fighting General - The Public and Private Campaigns of General Sir Walter Walker, Londyn 1973, s. 131-152.

33 D. Easter, Britain and the Confrontation with Indonesia 1960-1966, Londyn 2004, s. 46; J.S. Davinson, From Rebellion to Riots: Collective Violence on Indonesia Borneo, Singapur 2009, s. $52-53$.

34 S. Narine, Explaining ASEAN: Regionalism in Southeast Asia, Londyn 2002, s. 12.

35 G. Poulgrain, The Genesis of Konfrontasi: Malaysia, Brunei and Indonesia, 1945-1965, Bathurst 1998, s. 1-2. 
Podobnego zdania jest Hamilton Fish Armstrong, według którego konflikt indonezyjsko-malezyjski o Borneo był dla prezydenta Indonezji „pierwszym ruchem w grze zmierzającej do aneksji malezyjskich prowincji Sarawak i Sabah, jak również bogatego w ropę niewielkiego Sułtanatu Brunei, po podporządkowaniu którego miałby otwartą drogę do zajęcia Singapuru - jednego z najlepiej prosperujących portów świata, a dalej całej Malezji”36.

36 Ibidem, s. 2-3. 